\title{
ANALISIS YURIDIS PENDEKATAN HOLISTIK DALAM ANTROPOLOGI HUKUM MENURUT PARA AHLI
}

\author{
FORLIUS ZALUKHU \\ Email: hogoromootsuki180@gmail.com \\ No BP: 2110003600233 \\ UNIVERSITAS EKASAKTI PADANG
}

\section{A. PENDAHULUAN}

Menurut Kamus Hukum, kata yuridis berasal dari kata Yuridisch yang berarti menurut hukum atau dari segi hukum. Dapat disimpulkan tinjauan yuridis berarti mempelajari dengan cermat, memeriksa (untuk memahami), suatu pandangan atau pendapat dari segi hukum. Pendekatan yang digunakan Antropologi Hukum dalam mengkaji hukum adalah menggunakan pendekatan Holistik (menyeluruh) terhadap seluruh aspek kehidupan manusia antara lain hukum, ekonomi, politik, termasuk budaya. Di dalam Antropologi, kita belajar sesuatu yang holistik dalam melihat kebudayaan. Artinya, dengan penglihatan holistik dimaksudkan dapat meninjau kebudayaan sebagai suatu kesatuan yang bagian-bagiannya mewujudkan hubungan yang kait mengkait/terintegrasi. Dan hukum disini, tidak ditinjau secara tersendiri, tetapi dihubungan dengan kebudayaan sebagai keseluruhan. Pendekatan holistik termasuk dalam bagian disiplin akademis yang didalamnya mempelajari berbagai aspek yang ada kaitannya dengan manusia sekaligus lingkungan sosialnya, sehingga ditekankan pada penggunaan metode ilmiah dalam mempelajari manusia, untuk metode ilmiah tersebut mulai dari metode kuantitatif dan kualitatif.

Penelitian ini memusatkan perhatian pada kajian Antropologi Hukum tentang hubunganhubungan hukum dalam lapangan pekerjaan bangunan di Pematangsiantar. Berbicara mengenai hukum dalam Antropologi, berarti juga berbicara mengenai kebudayaan. Hukum tidak ditinjau 
secara tersendiri, tetapi dihubungkan dengan kebudayaan sebagai keseluruhan (Ihromi,2000:2). Karena pada konsep nya, hukum memberi pedoman bagi warga masyarakat mengenai apa yang boleh dan apa yang tidak (normatif)1, dan dalam hal apa (kognitif)2 (F.Benda-Beckmann, dalam Irianto, 2005:65). Kebudayaan merupakan unsur penting dalam keberlanjutan suatu bangsa, kemajemukan budaya bangsa Indonesia tercermin dalam berbagai aspek kehidupan dengan latar belakang sosio budaya yang beranekaragam. Keanekaragaman budaya yang ada membuktikan bahwa masyarakat memiliki kualitas produksi budaya yang luar biasa, jika mengacu pada pengertian kebudayaan adalah hasil cipta manusia. Menurut A. L. Krober dan C. Kluckhon, kebudayaan adalah manifestasi atau penjelmaan kerja jiwa manusia dalam arti seluas-luasnya. Menurutnya, Kebudayaan terdiri atas berbagai pola, bertingkah laku, mantap, pikiran, perasaan dan reaksi yang diperoleh dan terutama diturunkan oleh simbol-simbol yang menyusun pencapaiannya secara tersendiri dari kelompok-kelompok manusia, termasuk didalamnya perwujudan benda-benda materi, pusat esensi kebudayaan terdiri atas tradisi dan cita-cita atau paham, dan terutama keterikatan terhadap nilai-nilai dalam sistem nilai budaya yang telah melekat dengan kuatnya dalam jiwa setiap anggota masyarakat, sehingga sulit diganti atau dirubah untuk waktu yang singkat. Masyarakat dan kebudayaan dimanapun selalu dalam keadaan berubah baik perubahan jumlah dan komposisi di lingkungan sendiri, perubahan lingkungan alam dan fisik tempat mereka hidup, adanya difusi kebudayaan, penemuan-penemuan baru baik teknologi dan inovasi. 


\section{B. PEMBAHASAN}

Pendekatan holistik adalah bagian daripada proses pembelajaran dengan menjadikan segala hal bercampur menjadi satu kesatuan wilayah kekuatan yang utuh sehingga membuat seseorang bisa berpikir dan menganalisis suatu hal dari berbagai sisi, bahkan dari sisi yang tidak disadarinya sekalipun. Adapun definisi pendekatan holistik menurut para ahli, antara lain;

1. Marsh (2001), Pendekatan holistik adalah proses pembalajaran dan pemberian arti pendidikan yang dilakukan dengan upaya penghargaan dengan membentuk kolaboratif saling melengkapi bagi jawab guru kelas dan guru kelas khusus kepada para peserta didiknya.

2. Goodman (1986), Arti pendekatan holistik yakni sebuah konsepsi yang berusaha memberikan acuan tentang beragam permasalahan dalam kelompok sosial masyarakat dengan lebih bersifat spesifik serta kontekstual terhadap permasalahan yang terjadi.

Definisi yang dapat diterima Antropologi Hukum adalah rumusan dari Hoebel yakni suatu norma sosial adalah hukum. Bila terjadi pelanggaran atau tindakan tidak mengindahkan norma sosial maka yang melanggar akan diberikan sanksi, baik dalam bentuk sanksi tindakan fisik, diberikan sanksi sosial dan sanksi yang lainnya oleh yang mempunyai wewenang bertindak. Di dalam Antropologi, kita belajar sesuatu yang holistik dalam melihat kebudayaan. Artinya, dengan penglihatan holistik dimaksudkan dapat meninjau kebudayaan sebagai suatu kesatuan yang bagian-bagiannya mewujudkan hubungan yang kait mengkait/terintegrasi. Dan hukum disini, tidak ditinjau secara tersendiri, tetapi dihubungan dengan kebudayaan sebagai keseluruhan. 
Hubungan antara kebudayaan dan hukum, antara lain :

- Kebudayaan melahirkan norma, dan norma menunculkan hukum

- Norma bersifat universal

Artinya dipakai untuk berinteraksi sosial dengan masyarakat luas. Sehingga hukum difungsikan untuk sarana untuk melesatrikan kebudayaan yang terwujud di dalam norma social (Ihromi, 2000:1). Pada tahap awal perkembangannya, hukum di artikan oleh Malinowski sebagai sarana pengendalian sosial yang terdapat dalam setiap lapisan sosial masyarakat yang ketaatannya didasarkan atas hubungan timbal balik antar masyarakat yang saling berinteraksi. "Hukum tidak semata-mata terdapat dalam masyarakat yang terorganisasi dalam Negara, tetapi hukum sebagai sarana pengendalian sosial (legal order) terdapat dalam setiap bentuk masyarakat. Hukum dalam masyarakat bukan ditaati karena adanya tradisi ketaatan yang bersifat otomatisspontan, tetapi karena adanya prinsip timbalbalik (principle of reciprocity) dan prinsip publisitas (principle of publicity) misalnya sistem pertukaran sosial yang berkembang dalam masyarakat Trobiand menjadi pengikat sosial dan daya dinamis yang menggerakkan kehidupan ekonomi dan sosial masyarakat melalui prinsip resiprositas atau timbal-balik dalam bentuk pertukaran benda dan tenaga, menggerakkan kehidupan kekerabatan, sistem pertukaran mas kawin dan juga menggerakkan hubungan antar kelompok dalam bentuk upacara-upacara yang berlangsung dalam kehidupan bersama. (Suryatni, 2013:31).” Dari definisi Malinowski tersebut dapat diambil kesimpulan bahwa masyarakat mana pun, baik itu masyarakat yang masih sederhana atau sudah kompleks memiliki aturan-aturan hukum yang secara informal terlihat sebagai sarana pengendalian sosial di dalam interaksinya. Dan hukum disini masih dianggap sebagai sesuatu yang dapat memberikan perlakukan adil dalam hubungan timbal balik antar sesama individu 
maupun antar kelompok. Pada prinsipnya hukum (dalam rule centered paradigm) dipandang sebagai cara untuk meningkatkan integrasi sosial, dan merupakan akumulasi atau abstraksi dari norma-norma dan kebiasaan-kebiasaan yang dianut sebagai pedoman berperilaku. (Irianto, 2005: 64). Ciri ini juga bisa disebut sebagai hukum substantif, dimana hukum didasarkan atas hak-hak individu, moralitas, keadilan, dan kesejahteraan bagi individu tersebut (Bedner, 2012 :52). Hukum dalam pendekatan kritik dipandang sebagai cara untuk mendefinisikan dan menegakkan tata tertib yang menguntungkan kelompok tertentu diatas pengorbanan kelompok lain. Hukum tidak dipandang sebagai norma yang berasal dari konsensus sosial, tetapi ditentukan dan dijalankan oleh kekuasaan, dan substansi hukum dijelaskan dari kacamata kepentingan mereka yang sangat berkuasa, dengan cara membangun false consciousness (Wallace dan Wolf, dalam Irianto,2005:65). Dalam pendefinisian ini, hukum dicirkan seperti hukum formal, dimana hukum bersifat upbottom, hukum berasal dari regulasi pemerintah (Bedner, 2012 : 64). Dan dalam pemikiran prosesual, hukum dipandang sebagai gejala sosial atau proses sosial, artinya hukum selalu berada dalam pergerakan (dinamika), karena dipersepsikan, diberi makna dan kategori secara beragam dan berubah sepanjang waktu (Irianto, 2005:66). Aturanaturan hukum berbeda dengan aturan-aturan lainnya, dimana didukung oleh sanksisanksi dalam pengendalian sosialnya. Karena hukum berada dalam interaksi sosial masyarakat. Untuk mengendalikan interaksi tersebut, di ciptakan lah hukum. Dan hukum ini terdapat di dalam hubungan timbal balik maupun hubungan yang didasarkan atas pemenuhan hak-hak nya (Soekanto, 1984:1). Beckmann beranggapan bahwa hukum dianggap sebagai aturan-aturan yang diberi sanksi dalam prosedur terorganisasi (dalam Ihromi, 1993:6). Antropologi dalam melihat hukum sebagai suatu aspek dari kebudayaan, yaitu suatu aspek yang digunakan oleh kekuasaan masyarakat yang teratur dalam mengatur perilaku manusia dan masyarakat agar tidak terjadi penyimpangan dan agar 
penyimpangan yang terjadi dari norma-norma sosial yang telah ditentukan dapat diperbaiki. Dengan demikian, perilaku yang menjadi kebiasaan, dan selanjutnya menjadi adat masyarakat dan merupakan sistem kontrol sosial itu akan mempunyai kekuatan hukum, yang apabila digunakan oleh kekuasaan masyarakat untuk mengatur perilaku manusia dan masyarakat yang bersangkutan supaya teratur. Sepanjang masyarakat itu teratur, karena ada yang mengatur dan mempunyai kekuasaan, maka pada masyarakat itu terdapat hukum. (Hadikusuma, 2006:8). Dan ia menambahkan bahwa jika tidak ada petugas-petugas masyarakat atau perangkat penguasa dalam suatu masyarakat maka hukum itu tidak ada. Nurjaya (2011 :1) dalam tulisannya mengenai perkembanguan pluralisme hukum ia merujuk dalam berbagai ahli dan menyimpulkan bahwa para ahli antropologi mempelajari hukum bukan semata-semata sebagai produk dari hasil abstraksi logika sekelompok orang yang diformulasikan dalam bentuk peraturan perundangundangan semata, tetapi lebih mempelajari hukum sebagai perilaku dan proses sosial yang berlangsung dalam kehidupan masyarakat. Hoebel menambahkan bahwa hukum itu ada pada masyarakat yang sederhana, yang dinamakan dengan ,primitive law”, ada pada masyarakat purba "archeiv law" dan hukum itu ada pada masyarakat yang telah maju dengan hukumnya yang modern (Hoebel dalam Hadikusuma, 2006:8).

Hukum dalam perspektif antropologi dipelajari sebagai bagian yang integral dari kebudayaan secara keseluruhan, dan karena itu hukum dipelajari sebagai produk dari interaksi sosial yang dipengaruhi oleh aspek-aspek kebudayaan yang lain, seperti politik, ekonomi, ideologi, religi, struktur sosial, dll,atau hukum dipelajari sebagai proses sosial yang berlangsung dalam kehidupan masyarakat. Karena itu, hukum dalam perspektif antropologi bukan sematamata berwujud peraturan perundang-undangan yang diciptakan oleh Negara (state law), tetapi juga hukum dalam wujudnya sebagai peraturan-peraturan lokal yang bersumber dari suatu 
kebiasaan masyarakat (customary law/folk law), termasuk pula di dalamnya mekanismemekansime pengaturan dalam masyarakat (self regulation) yang juga berfungsi sebagai sarana pengendalian sosial (legal order). (Pospisil dan Moore dalam Nurjaya,2011:1). Secara antropologis bentuk mekanisme-mekanisme pengaturan sendiri (inner order mechanism atau self-regulation) dalam komunitas-komunitas masyarakat adalah merupakan hukum yang secara lokal berfungsi sebagai sarana untuk menjaga keteraturan sosial (F. von Benda-Beckmann dalam Suryatni, 2013:34). Seperti yang disampaikan juga oleh Hollemann (1978) mengatakan bahwa di wilayah urban di negara-negara berkembang, tumbuh bentuk-bentuk hukum baru yang tidak dapat di beri label sebagai hukum negara, hukum adat, atau hukum agama, sehingga disebut sebagai hybrid law, atau unnamed law (dalam Irianto,2012). Teori-teori tersebut saya bawa ke lapangan, dan membuktikan bahwa ternyata benar bahwa ada kebiasaan-kebiasaan dalam dunia pertukangan yang tanpa sadar sudah di berlakukan sebagai hukum dalam dunia pertukangan. Dilihat dari keeksisan hukum dalam masyarakat, Paul J. Bohannan mengatakan bahwa hukum itu mirip seperti bunglon bila diperhatikan bahwa dia terdapat diberbagai masyarakat dan dia mengambil bentuk dan isi menurut kebutuhan masyarakat dimana dia berlaku. Namun dibawah kulit bunglon yang berubah-ubah terdapat sesuatu yang merupakan inti yang tidak berubah. Sifatnya yang bisa berubah itu justru merupakan sifat yang paling penting dan merupakan kekuatannya(dalam Ihromi,2000:52-53). Dan Hoebel juga menambahkan bahwa untuk dapat menempatkan hukum di dalam struktur masyarakat sosial, maka kita lebih dahulu harus melihat kepada masyarakat dan kebudayaannya sebagai suatu keseluruhan (dalam Ihromi,1993:148). Sehingga dapat kita lihat bahwa hukum itu bergerak sangat dinamis, karena dapat berubah sepanjang waktu. Dengan semakin berkembangnya pemikiran dan pengetahuan masyarakat, seorang antropolog bernama Klose menuliskan sebuah perbedaan pandangan antara 
masyarakat terbuka dan masyarakat tertutup dalam melihat hukum. Pada masyarakat terbuka cenderung memiliki sikap kritis terhadap kehidupan sosial mereka, yang mana mereka melihat bahwa norma/aturan yang mengatur kehidupan sehari-hari dan lembaga yang mengaturnya merupakan karya manusia itu sendiri. Sedangkan masyarakat tertutup menilai bahwa norma/aturan dan institusi yang mengaturnya dianggap pemberian dari alam (dalam Birx, 2011: Dari berbagai macam pandangan dan pendefinisian diatas dapat disimpulkan bahwa hukum terdapat di mana-mana. Baik itu dalam bentuk-bentuk masyarakat, lapisan masyarakat, di periode kehidupan zaman dulu, masa kini, dan masa mendatang yang pergerakannya sangat dinamis dan keeksisannya hidup dalam interaksi masyarakat dan berfungsi sebagai kontrol sosial. Karakteristik khas yang ada dalam proses pendekatan holistik. Antara lain;

1. Terjadi keterpaduan dalam proses kajian

2. Lebih menghargai proses pembelajaran terkait dengan pengamalaman

3. Lebih berorientasi pada proses dan hasil dari konsep yang diajarkan

4. Meberikan kesan kolaboratif terhadap permasalahan tertentu

5. Terjadi proses refleksi dan konstruksi terkait dengan pemahaman secara dinamis 


\section{C.PENUTUP}

Pendekatan holistik adalah bagian daripada proses pembelajaran dengan menjadikan segala hal bercampur menjadi satu kesatuan wilayah kekuatan yang utuh sehingga membuat seseorang bisa berpikir dan menganalisis suatu hal dari berbagai sisi, bahkan dari sisi yang tidak disadarinya sekalipun. Pendekatan holistik adalah proses pembalajaran dan pemberian arti pendidikan yang dilakukan dengan upaya penghargaan dengan membentuk kolaboratif saling melengkapi bagi jawab guru kelas dan guru kelas khusus kepada para peserta didiknya.

Arti pendekatan holistik yakni sebuah konsepsi yang berusaha memberikan acuan tentang beragam permasalahan dalam kelompok sosial masyarakat dengan lebih bersifat spesifik serta kontekstual terhadap permasalahan yang terjadi. Norma bersifat universal Artinya dipakai untuk berinteraksi sosial dengan masyarakat luas. Sehingga hukum difungsikan untuk sarana untuk melesatrikan kebudayaan yang terwujud di dalam norma social.Pada tahap awal perkembangannya, hukum di artikan oleh Malinowski sebagai sarana pengendalian sosial yang terdapat dalam setiap lapisan sosial masyarakat yang ketaatannya didasarkan atas hubungan timbal balik antar masyarakat yang saling berinteraksi. «Hukum tidak semata-mata terdapat dalam masyarakat yang terorganisasi dalam Negara, tetapi hukum sebagai sarana pengendalian sosial terdapat dalam setiap bentuk masyarakat. Hukum dalam masyarakat bukan ditaati karena adanya tradisi ketaatan yang bersifat otomatis-spontan, tetapi karena adanya prinsip timbalbalik dan prinsip publisitas misalnya sistem pertukaran sosial yang berkembang dalam masyarakat Trobiand menjadi pengikat sosial dan daya dinamis yang menggerakkan kehidupan ekonomi dan sosial masyarakat melalui prinsip resiprositas atau timbal-balik dalam bentuk pertukaran benda dan tenaga, menggerakkan kehidupan kekerabatan, sistem pertukaran mas kawin dan juga menggerakkan hubungan antar kelompok dalam bentuk upacara-upacara yang berlangsung 
dalam kehidupan bersama. Dari definisi Malinowski tersebut dapat diambil kesimpulan bahwa masyarakat mana pun, baik itu masyarakat yang masih sederhana atau sudah kompleks memiliki aturan-aturan hukum yang secara informal terlihat sebagai sarana pengendalian sosial di dalam interaksinya. Dan hukum disini masih dianggap sebagai sesuatu yang dapat memberikan perlakukan adil dalam hubungan timbal balik antar sesama individu maupun antar kelompok. Pada prinsipnya hukum dipandang sebagai cara untuk meningkatkan integrasi sosial, dan merupakan akumulasi atau abstraksi dari norma-norma dan kebiasaan-kebiasaan yang dianut sebagai pedoman berperilaku. . Ciri ini juga bisa disebut sebagai hukum substantif, dimana hukum didasarkan atas hak-hak individu, moralitas, keadilan, dan kesejahteraan bagi individu tersebut. Hukum dalam pendekatan kritik dipandang sebagai cara untuk mendefinisikan dan menegakkan tata tertib yang menguntungkan kelompok tertentu diatas pengorbanan kelompok lain. Hukum tidak dipandang sebagai norma yang berasal dari konsensus sosial, tetapi ditentukan dan dijalankan oleh kekuasaan, dan substansi hukum dijelaskan dari kacamata kepentingan mereka yang sangat berkuasa, dengan cara membangun false consciousness . Dalam pendefinisian ini, hukum dicirkan seperti hukum formal, dimana hukum bersifat upbottom, hukum berasal dari regulasi pemerintah. Dan dalam pemikiran prosesual, hukum dipandang sebagai gejala sosial atau proses sosial, artinya hukum selalu berada dalam pergerakan, karena dipersepsikan, diberi makna dan kategori secara beragam dan berubah sepanjang waktu . Aturanaturan hukum berbeda dengan aturan-aturan lainnya, dimana didukung oleh sanksisanksi dalam pengendalian sosialnya. Karena hukum berada dalam interaksi sosial masyarakat. Untuk mengendalikan interaksi tersebut, di ciptakan lah hukum. Dan hukum ini terdapat di dalam hubungan timbal balik maupun hubungan yang didasarkan atas pemenuhan hak-hak nya . Beckmann beranggapan bahwa hukum dianggap sebagai aturan-aturan yang diberi 
sanksi dalam prosedur terorganisasi . Antropologi dalam melihat hukum sebagai suatu aspek dari kebudayaan, yaitu suatu aspek yang digunakan oleh kekuasaan masyarakat yang teratur dalam mengatur perilaku manusia dan masyarakat agar tidak terjadi penyimpangan dan agar penyimpangan yang terjadi dari norma-norma sosial yang telah ditentukan dapat diperbaiki. Dengan demikian, perilaku yang menjadi kebiasaan, dan selanjutnya menjadi adat masyarakat dan merupakan sistem kontrol sosial itu akan mempunyai kekuatan hukum, yang apabila digunakan oleh kekuasaan masyarakat untuk mengatur perilaku manusia dan masyarakat yang bersangkutan supaya teratur. Sepanjang masyarakat itu teratur, karena ada yang mengatur dan mempunyai kekuasaan, maka pada masyarakat itu terdapat hukum. 


\section{DAFTAR PUSTAKA}

Darmini Roza dan Laurensius Arliman S, Peran Pemerintah Daerah Di Dalam Melindungi Hak Anak Di Indonesia, Masalah-Masalah Hukum, Volume 47, Nomor 1, 2018. https://doi.org/10.14710/mmh.47.1.2018.10-21

Laurensius Arliman S, Peranan Metodologi Penelitian Hukum di Dalam Perkembangan Ilmu Hukum di Indonesia, Soumatera Law Review, Volume 1, Nomor 1, 201. http://doi.org/10.22216/soumlaw.vli1.3346.

Laurensius Arliman S, Peran Badan Permusyawaratan Desa di Dalam Pembangunan Desa dan Pengawasan Keuangan Desa, Padjadjaran Journal of Law, Volume 4, Nomor 3, 2017. https://doi.org/10.15408/jch.v4i2.3433.

Laurensius Arliman S, Penanaman Modal Asing Di Sumatera Barat Berdasarkan UndangUndang Nomor 25 Tahun 2007 Tentang Penanaman Modal, Supremasi Hukum, Volume 1, Nomor 1, 2018. http://dx.doi.org/10.36441/hukum.vli01.102.

Laurensius Arliman S, Memperkuat Kearifan Lokal Untuk Menangkal Intoleransi Umat Beragama Di Indonesia, Ensiklopedia of Journal, Volume 1, Nomor 1, 2018, https://doi.org/10.33559/eoj.v1i1.18.

Laurensius Arliman S, Perkawinan Antar Negara Di Indonesia Berdasarkan Hukum Perdata Internasional, Kertha Patrika, Volume 39, Nomor 3, 2017, https://doi.org/10.24843/KP.2017.v39.i03.p03.

Laurensius Arliman S, Partisipasi Masyarakat Di Dalam Pengelolaan Uang Desa PascaUndangUndang Nomor 6 Tahun 2014 Tentang Desa, Jurnal Arena Hukum, Volume 12, Nomor 2, 2019, https://doi.org/10.21776/ub.arenahukum.2019.01202.5.

Laurensius Arliman S, Mewujudkan Penegakan Hukum Yang Baik Di Negara Hukum Indonesia, Dialogica Jurnalica, Volume 11, Nomor 1, 2019, https://doi.org/10.28932/di.v11i1.1831.

Laurensius Arliman S, Mediasi Melalui Pendekatan Mufakat Sebagai Lembaga Alternatif Penyelesaian Sengketa Untuk Mendukung Pembangunan Ekonomi Nasional, UIR Law Review, Volume 2, Nomor 2, 2018, https://doi.org/10.25299/uirlrev.2018.vol2(02).1587

Laurensius Arliman S, Peranan Filsafat Hukum Dalam Perlindungan Hak Anak Yang Berkelanjutan Sebagai Bagian Dari Hak Asasi Manusia, Doctrinal, Volume 1, Nomor 2,2016.

Laurensius Arliman S, Ni Putu Eka Dewi, Protection of Children and Women's Rights in Indonesiathrough International Regulation Ratification, Journal of Innovation, Creativity and Change Volume 15, Nomor 6, 2021.

Laurensius Arliman S, Gagalnya Perlindungan Anak Sebagai Salah Satu Bagian Dari Hak Asasi Manusia Oleh Orang Tua Ditinjau Dari Mazhab Utilitarianisme, Jurnal Yuridis, Volume 3, Nomor 2, 2016, http://dx.doi.org/10.35586/.v3i2.180.

Laurensius Arliman S, Tantangan Pendidikan Kewarganegaraan Pada Revolusi 4.0, Jurnal Ensiklopedia Sosial Review, Volume 2, Nomor 3, $2020 .$. 
